\title{
KONSTITUSIONALITAS PENGHAYAT ALIRAN KEPERCAYAAN DALAM SISTEM HUKUM NASIONAL DAN HUKUM ISLAM
}

\author{
Riesky Milly Valdo. MY', Afdil Azizi ${ }^{2}$ \\ ${ }^{1}$ Institut Agama Islam Negeri (IAIN) BatusangkarFakultas Syariah \\ e-mail: reiskymillyvaldo12@gmail.com \\ ${ }^{2}$ Pengadilan Negeri Solok
}

\begin{abstract}
The main problem in this thesis is where the writer wants to see how the constitutionality of Beliefs in Indonesia is in the national legal system and Islamic law, which in national law has been explained a lot in the legal umbrella starting from the 1945 Constitution to the Decree. The minister and most recently are related to the Constitutional Court Decision Number 97 / PUU-XIV / 2016. The author also wants to see how the views of Islamic law on followers of this belief.
\end{abstract}

Kata kunci: Konstitusionalitas, Hukum Nasional, Hukum Islam

\section{PENDAHULUAN}

P ada tanggal 23 Mei 2019 Presiden Republik Indonesia Joko Widodo mengeluarkan Peraturan Pemerintah Nomor 40 Tahun 2019 Tentang Pelaksanaan Undang-Undang Nomor 23 Tahun 2006 Tentang Administrasi Kependudukan sebagaimana telah diubah dengan Undang-Undang Nomor 24 Tahun 2013 Tentang Perubahan atas Undang-Undang Nomor 23 Tahun 2006 Tentang Administrasi Kependudukan. Dengan peraturan pemerintah ini Presiden Republik Indonesia mengingatkan kembali bahwa penghayat kepercayaan sudah punya hak yang sama, terlihat pada Pasal 39 tentang proses perkawinan penghayat kepercayaan.

Dalam sejarah kebijakan pemerintah Indonesia tentang agama dan aliran kepercayaan, perjalanan menuai pro dan kontra. Diawali dari Departemen Agama pada tahun 1961 yang mengajukan definisi "agama". Menurutnya, suatu agama harus memuat unsur-unsur penting ini;

(1) Kepercayaan pada Tuhan Yang Maha Esa,

(2) Mempunyai nabi,

(3) Kitab suci,

(4) Umat,

(5) Sistem hukum bagi penganutnya (Budhy Munawar-Rachman \{editor\}, 2010: 98)

Dengan memperhatikan pokok-pokok tentang pluralisme dan multikulturalisme dan dihubungkan dengan kondisi Negara Indonesia saat ini, kiranya menjadi jelas bahwa pluralisme beragama perlu dikembangkan di Indonesia, karena justru dengan gagasan inilah kita dapat memaknai keragaman agama dan budaya di Indonesia tanpa melanggar hak-hak asasi antar kelompok. 
Dari pemikiran diatas, ketika demokrasi diadopsi oleh Negara Indonesia sebagai role model, maka yang harus diperhatikan adalah posisi Negara Indonesia sebagai Negara religious yang berdasarkan Pancasila. Negara Indonesia tidak membenarkan dan tidak mentolerir adanya pemahaman yang anti-Tuhan (atheism). Negara Indonesia juga tidak mentolerir berbagai upaya yang ingin memisahkan agama dari Negara (secularism).(Kamarudin,2013:170- 171).

Mengenai persoalan agama dalam Islam kita bisa melihat ke Surah Al- Kafirun yakni sesudah Allah menyatakan tentang tidak mungkin ada persamaan sifat antara Tuhan yang disembah oleh Nabi Muhammad SAW dengan yang disembah oleh orangorang kafir, maka dengan sendirinya tidak ada pula persamaan dalam hal ibadah. (Departemen Agama RI,2015:798).

Melihat hubungan atau ketentuan maupun kepastian hukum mengenai agama dan aliran kepercayaan, selain dari kajian hukum positif penulis juga akan mengkajinya dalam ruang lingkup Hukum Tata Negara Islam untuk melihat bagaimana konstitusionalitas penghayat aliran kepercayaan dalam sistem ketatanegaraan di Indonesia.

Sampai sekarang banyak sekali aliran kepercayaan seperti Kaharingan di Kalimantan, Sunda Wiwitan di Jawa Barat dan Banten, serta Parmalim di Sumatera Utara yang sulit untuk diterima oleh kalangan masyarakat termasuk penulis sendiri karna menganggap atau mengakui hanya enam agama yang ada di Indonesia ini, namun dalam dasar hukum yang dijelaskan di atas aliran penghayat kepercayaan sudah di jelaskan. Kata-kata yang paling sering digunakan oleh para ahli hukum ketika memuji atau mencela hukum atau pelaksanaannya adalah kata "adil "e dan „tidak adil ", dan mereka seringkali menulis seolah-olah ide keadilan dan moralitas adalah dua hal yang tinggal berdampingan. Memang ada alasan yang amat kuat mengapa keadilan memiliki kedudukan paling menonjol dalam kritik atas tatanan hukum, namun kita perlu melihat bahwa keadilan adalah segmen lain moralitas, dan bahwa hukum dan pelaksaan hukum bisa jadi memiliki atau tidak memiliki jenis kelebihan yang berbeda pula.

\section{METODE PENELITIAN}

Dalam penelitian ini penulis menggunakan jenis penelitian hukum normatif, yaitu mencakup tentang asas-asas hukum. Selain itu penelitian ini juga mengkaji dan meneliti peraturan perundang-undangan. Teknik pengumpulan data yang penulis beberapa peraturan yang ada di Indonesia mulai dari Undang-Undang Dasar 1945 sampai dengan Peraturan Daerah. Namun di dalam hukum Islam tidak memperbolehkan adanya Aliran Kepercayaan tetapi juga tidak melarang orang lain selain orang yang beragama Islam menganut Aliran Kepercayaan karna dijelaskan dalam Al-quran “untukmu agamamu dan untukku gunakan adalah dengan menggunakan data kepustakaan. Untuk menetapkan keabsahan data (trustworthiness) penulis menggunakan teknik trigulasi atau mecari informasi lain tentang suatu topik yang digali, lebih dari satu sumber.

\section{HASIL DAN PEMBAHASAN}




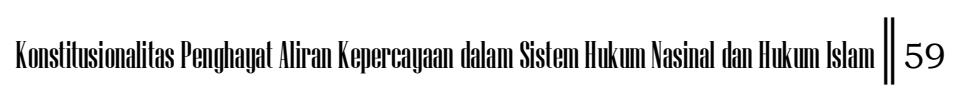

\section{Kedudukan Aliran Penghayat Kepercayaan dengan Agama dalam Sistem Ketatanegaran di Indonesia}

Menurut pendapat penulis, konsep negara hukum yang menyatakan bahwa tindakan negara atau pemerintah yang berdasarkan atas aturan hukum, dan negara atau pemerintah wajib melindungi Hak Asasi Manusia warga negara. Konsekuensinya mengharuskan negara atau pemerintah untuk membuat aturan-aturan hukum yang akan menjadi instrumen pengatur hak dan kewajiban negara atau pemerintah dalam penyelenggaraan negara sekaligus mengatur dan melindungi hak dan kewajiban warga negara. Implementasi pemenuhan hak konstitusional dalam administrasi kependudukan bagi penghayat kepercayaan sebelum Putusan Mahkamah Konstitusi Republik Indonesia Nomor 97/PUU- XIV/2016 yang dilakukan oleh negara atau pemerintah melalui Dinas Kependudukan dan Catatan Sipil dilakukan dengan tidak melaksanakan Undang-Undang Administrasi Kependudukan, karena dalam pengurusan Kartu Keluarga, kolom agama sudah dapat diisi dengan status sebagai penghayat kepercayaan.

Implementasi pemenuhan hak konstitusional para penghayat kepercayaan dalam dokumen administrasi kependudukan Kartu Tanda Penduduk elektronik (KTP-el) dilakukan dengan tetap merujuk pada Undang- Undang Nomor 24 Tahun 2013 tentang Perubahan Atas Undang-Undang Nomor 23 Tahun 2006 Tentang Administrasi Kependudukan, yaitu kolom agama dalam KTP-el penghayat kepercayaan tetap dikosongkan, Undang- Undang Administrasi Kependudukan sebagai instrumen pengaturan hukum menyatakan bahwa pengosongan kolom agama dilakukan untuk KTPel dan Kartu Keluarga bagi penghayat kepercayaan.

Perkembangan terbaru hingga saat ini, pasca Putusan Mahkamah Konstitusi Republik Indonesia Nomor 97/PUU-XIV/2016, secara perlahan negara melalui pemerintah (Menteri Dalam Negeri, Dinas Kependudukan dan Catatan Sipil) mulai melakukan langkah-langkah untuk melaksanakan Putusan Mahkamah Konstitusi Republik Indonesia Nomor 97/PUU-XIV/2016 yaitu dengan menerbitkan Peraturan Mentri Dalam Negri Nomor 118 Tahun 2017 tentang Blangko Kartu Keluarga, Register, dan Kutipan Akta Pencatatan Sipil. Langkah selanjutnya yang dilakukan pemerintah adalah Kementerian Dalam Negeri melakukan penyesuaian secara teknis dalam Sistem Informasi Administrasi Kependudukan (SIAK) agar lebih mudah diaplikasikan oleh para petugas pelayanan di Dinas Kependudukan dan Catatan Sipil Kabupaten/ Kota di seluruh Indonesia.

\section{Tinjauan Hukum Tata Negara Islam atas Aturan Aliran Penghayat Kepercayaan dalam Hubungannya dengan Agama}

Islam adalah agama yang mementingkan kemaslahatan dan kebahagiaan manusia, baik didunia maupun di akhirat. Ajarannya tetap aktual bagi manusia di segala zaman dan tempat. Islam tidak hanya merupakan rahmat bagi manusia, tetapi juga bagi alam semesta. Islam memperlakukan manusia secara adil tanpa membeda-bedakan kebangsaan, warna kulit dan agamanya. Berdasarkan prinsip ini maka Islam membuat berbagai 
ketentuan yang mengatur hubungan antar sesama manusia, baik muslim sendiri maupun non-muslim. (Muhammad Iqbal,2001,231).

Islam mengatur kebebasan beragama dan berkeyakinan, melindungi hak warga negara sekalipun ia non-Islam dengan sebuah dasar-dasar kesatuan umat manusia, bahwa Islam mempunyai Prinsip Al-Adalah (keadilan), Al-Musawah (persamaan), Karomah insaniyah (kehormatan manusia) dan lain sebagainya. Kebebasan beragama dan berkeyakinan, dalam bentuk historisnya yang terkini adalah suatu hak asasi manusia yang dapat berlaku secara universal yang terkodifikasi dalam instrument- instrument hak asasi manusia Internasional. Dalam tataran normatif, telah jelas sejak pemulaan era hak asasi manusia modern bahwa kebebasan beragama atau berkeyakinan adalah hak fundamental, dan sesungguhnya satu dari hak-hak fundamental yang paling penting. (Tore Lindholm DKK, 2014, 19)

Syarieat Islam berbeda dengan yang lainnya dalam menetapkan persamaan hak secara mutlak yang tidak di putuskan kecuali sesuai dengan keadilan. Maka tidak ada ke ikatan dan tidak ada pengecualian. Persamaan hak adalah persamaan yang sepurna antara individu dengan rakyat.

Rasulullah saw, bersabda: Darah-darah orang mukmin seluruhnya sama, dan mereka berkuasa atas orang-orang selain mereka dan harus membantu dengan adanya jaminan mereka itu akan orang yang lemah dari mereka. Ketahuilah, seorang Muslim tidak diqishash dengan sebab membunuh seorang kafir, dan tidak boleh dibunuh orang kafir yang mempunyai perjanjian selama dalam masa perjanjian itu.

Rasulullah saw, memutuskan bahwa darah-darah kaum muslimin itu sama, artinya, setara dan tidak berbeda. Ini adalah persamaan yang sempurna antara semua kelompok dan persamaan sempurna antara semua umat dan jenis, juga persamaan sempurna antara penguasa dan rakyat biasa, persamaan antara non-Muslim dan Muslim dalam Negara Islam pada hak dan kewajiban, dan mereka masing-masing mempunyai agama dan jalan sendiri-sendiri. Juga persamaan dalam hak dan kewajiban antara laki-laki dan perempuan, kecuali apa yang di kecualikan dengan nash yang jelas yang di tuntut oleh perbedaanperbedaan alami antara keduanya; dan bukan karena kurangnya kemampuan prempuan.( Farid Abdul Khaliq 2005,231-235)

Sebagai negara yang memiliki pluralitas agama, tidak menjadikan Islam anti terhadap pluralitas tersebut. Sebab secara historis, istilah "pluralisme" diidentikan dengan sebuah aliran filsafat yang menentang konsep negara absolut dan berdaulat. Jika pluralisme klasik merupakan reaksi terhadap doktrin hukum tentang kedaulatan negara, pluralisme kontemporer yang muncul tahun 1950-an dikembangkan dengan tidak menentang kedaulatan negara, tetapi untuk menentang teori-teori tentang elit. Dan pada pluralisme kontemporer lah Islam menunjukan diri sebagai agama yang tidak ada pemisahan antara hubungan agama dan negara. (Nur Kholis,2016:67)

Apabila negara berada dalam lingkungan yang mempunyai pluralitas agama, maka secara otomatis Islam wajib menjaga hubungan baik dalam kehidupan pluralitas keberagamaan. Sebagaima dalam surah al- Kafirun telah memberi penjelasan, di mana Islam menghargai perbedaan agama. Hal ini menunjukkan sikap ajaran Islam yang toleran dan bentuk transparasi keyakinan. Tidak perlu melakukan tindakan berupa menjelek- 
jelekan atau mencaci-maki terhadap keyakinan orang lain, karena demikian ini sangat dilarang oleh Islam, sebagaimana dalam surah al-An"am ayat 108:

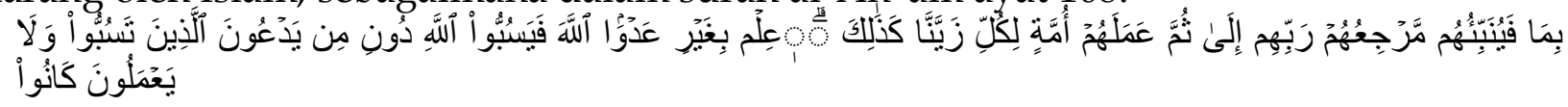

Artinya :"Janganlah kamu memaki sembahan-sembahan yang mereka sembah selain Allah". (Departemen Agama RI, 2009: 141)

Ayat ini sangat menekankan pentingnya menciptakan harmonisasi beragama. Larangan mencaci-maki tersebut ditunjukkan kepada orang yang berbeda keyakinan dan menjadi pedoman bagi pemeluk agama-agama.

Hal ini sering mengintai umat muslim yang mengakibatkan ketegangan beragama, apalagi yang namanya ketegangan beragama semata-mata tidak diakibatkan oleh pola dakwah yang kolot, tetapi pemahaman dan sikap pemeluk agama yang masih kurang menghayati pentingnya menghargai perbedaan keyakinan dalam beragama. Perbedaan memang jelas ada, apalagi perbedaan itu kaitannya dengan perbedaan agama. Setiap agama memiliki strategi dan misi untuk mentransformasikan nilai-nilai agama kepada umat manusia, sehingga nilai agama tersebut mampu untuk diterima dan diamalkan oleh pemeluk-pemeluknya. Maka, perbedaan tersebut tidak harus dipertentangkan sehingga harus ditakuti, tetapi harus menjadi titik tolak untuk berkompetisi menuju kebaikan, surah al- Maidah ayat 48 menegaskan hal ini;

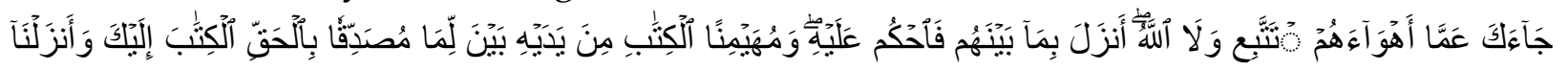

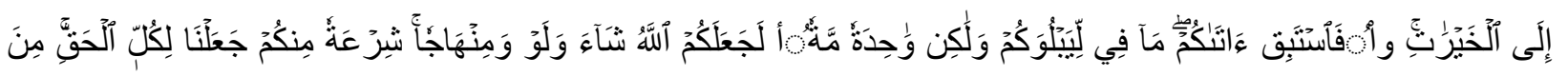

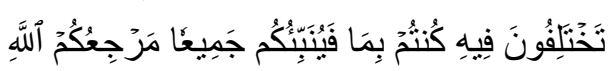

Artinya: "Dan kami telah turunkan kepadamu al-Kitab dengan hak, membenarkan apa yang sebelumnya dari kitab-kitab dan menjadi batu ujian terhadapnya; maka putuskan lah perkara di antara mereka menurut apa yang Allah turunkan dan janganlah engkau mengikuti hawa nafsu mereka dengan meninggalkan kebenaran yang telah datang kepadamu. Bagi masing-masing kami berikan aturan dan jalan yang terang; sekiranya Allah menghendaki niscaya kamu dijadikan-Nya satu umat, tetapi Allah hendak menguji kamu terhadap pemberian-Nya kepada kamu, maka berlomba-lomba lah berbuat kebaikan, hanya kepada Allah kembali semuanya, lalu diberitahukannya kepada kamu apa yang telah kamu perselisihkan dalam meghadapinya." (Departemen Agama RI,2009:116)

Islam adalah agama perdamaian, di dalamnya terdapat nilai-nilai yang mengajarkan sikap untuk menghargai, menghormati perbedaan keyakinan dan pendapat. Ajaran perdamaian merupakan inti dari toleransi beragama. Harmonisasi antar umat beragama tidak hanya pada level elit agama, tetapi pelaksanaan itu juga berada di level yang paling bawah. Harmonisasi antarumat beragama sesungguhnya telah disadari betul oleh para intelektual agama manapun, akan tetapi, apabila pemahaman tersebut tidak dipegang secara kuat, maka slogan menjalin kerukunan antarumat beragama hanya menjadi kesepakatan tertulis yang tidak memiliki tataran nilai apapun. Kembali mempertegas bahwa surah al-Kafirun mengatakan, "Bagimulah agamamu, dan bagikulah 
agamaku merupakan modal sosial dan kepekaan al-Qurean terhadap kehidupan sosial keagamaan yang multi religius, dan agama Islam yang toleran terhadap agama yang berbeda. Surah al-Kafirun ini menjadi cermin bagi para juru dakwah Islam yang mendambakan adanya kerukunan antarumat beragama dan sebagai dasar pijakan bahwa Islam sangat menghargai pihak lain yang dianggap berbeda dengan Islam.

Jika diamati, isi surah al-Kafirun ini memang perlu untuk dipahami dan dipraktekan oleh umat muslim di dunia, khususnya umat muslim di Indonesia yang kental sekali dengan kehidupan plural keagamaannya. Di samping itu, isi kandungan surah al-Kafirun membuktikan bahwa nilai Islam tentang harmonisasi antarumat beragama bersifat universal, sebagaimana hal ini telah dicontohkan oleh Nabi Muhammad Saw, bahwa Nabi tidak pernah menggunakan kekarasan untuk menegakkan syariat Islam dan tidak pernah melakukan serangan terhadap musuh, meskipun diketahui di masa awal Islam sering terjadi peperangan antara umat Islam dan kaum kafir. Nabi Saw., menjunjung tinggi nilai-nilai perbedaan tersebut dengan dibuktikan ketika Nabi Saw., memperoleh amanah untuk menjadi pemimpin di Madinah.

\section{PENUTUP}

Berdasarkan penelitian yang penulis lakukan dalam menjawab tentang bagaimana konstitusionalisme Penghayat Aliran Kepercayaan yang ada di Indonesia dalam sistem hukum nasional dan hukum islam dapat penulis simpulkan :

1. Bahwa perdebatan mengenai negara dan agama serta konstitusinalitas Penghayat Aliran Kepercayaan di Indonesia telah final akan tetapi Aliran Kepercayaan tidak bisa dikatakan sebagai agama, akan tetapi Aliran Kepercayaan adalah suatu kebudayaan leluhur yang ada di Indonesia. Oleh karena itu, sebagai bagian upaya negara dalam melindungi dan menjamin hak kebebasan beragama dan berkeyakinan warga negaranya, maka dirumuskanlah Pasal 28E ayat (1) dan ayat (2) dan Pasal 29 ayat (1) dan ayat (2) Undang-Undang Dasar 1945 dalam konstitusi tertulisnya. Pemahaman kebebasan beragama di Indonesia adalah bebas memeluk agama dan memilih salah satu agama yang diyakini berdasarkan pengakuannya terhadap Tuhan Yang Maha Esa, bukan bebas untuk tidak memilih agama (atheis). Serta pemahaman Menganut Aliran Kepercayaan dibolehkan asalkan memiliki unsur-unsur seperti kepercayaan kepada tuhan yang maha esa, memiliki nabi, memiliki kitab, memiliki umat serta memiliki sistem hukum bagi penganutnya. Namun demikian, tugas pemerintah dalam hal ini harus didasarkan melalui peraturan perundang- undangan, yaitu sebagaimana dimaksud dalam Pasal 28J Undang-Undang Dasar 1945 serta Putusan Mahkamah Konstitusi Republik Indonesia Nomor 97/PUU-XIV/2016 tentang Yudicial Review Undang-undang Administrasi Kependudukan.

2. Islam merupakan agama perdamaian, didalamnya terdapat nilai-nilai yang mengajarkan sikap untuk menghargai, menghormati perbedaan keyakinan dan pendapat. Tapi dalam Islam tetap tidak ada atau tidak boleh umatnya menganut aliran kepercayaan atau pandangan yang menyimpang. Seperti yang di jelaskan oleh Allah 
SWT dalam Alquran Surat Al-An "eam ayat 108 yang artinya “ janganlah kamu memaki sembahan-sembahan mereka selain Allah".

\section{DAFTAR PUSTAKA}

Undang-undang

Undang-undang Dasar 1945

Undang-undang Nomor 1/PNPS/1965 Tentang Pencegahan Penyalhgunaan Dan/Atau Penodaan Agama.

Undang-undang Nomor 39 Tahun 1999 Tentang Hak Asasi Manusia

Undang-undang Nomor 24 tahun 2013 Tentang Perubahan Atas Undang- Undang Nomor 23 Tahun 2006 tentang Administrasi Kependudukan

\section{TAP MPR Nomor: IV/ MPR/1978 tentang GBHN}

Peraturan Pemerintah nomor 40 Tahun 2019 Tentang pelaksanaan undang- undang nomor 23 tahun 2006 tentang administrasi kependudukan sebagaimana telah diubah dengan undang-undang nomor 24 tahun 2013 tentang perubahan atas undang-undang nomor 23 tahun 2006 tentang administrasi kependudukan.

Putusan Mahkamah Konstitusi Republik Indonesia, Pengujian UU Nomor 32 Tahun 2004 tentang Pemerintahan Daerah terhadap UUD 1945, Nomor 072-073/PUUII/2004.

Putusan Mahkamah Konstitusi Republik Indonesia Nomor 97/PUU-XIV/2016 Tentang Yudicial Review Undang-undang Administrasi Kependudukan.

\section{Buku}

Adji Silarus 2015, Sadar Penuh Hadir Utuh, Transmedia, Jakarta

Asshidiqie, Jimly, 2014. Konstitusi dan Konstitusionalisme Indonesia. Sinar Grafika, Jakarta.

Asshiddiqie, Jimly. 2006. Pengantar Ilmu Hukum Tata Negara 1. Sekretaris Jendral dan Kepaniteraan Mahmakah Konstitusi RI Kholik, Jakarta.

Cst Kansil, Christine S.t Kansil,Engelien R,palandeng dan Godlieb mamahit, 2009 Kamus Istilah Hukum, Jala Permata Aksara, Jakarta.

Darji Darmodiharjo, 1991. Pendidikan Pancasila. Usaha Nasional. Surabaya Depertemen Agama RI, 2009 Al-Hikmah: al-Qur'an dan Terjemahannya,Diponegoro, Bandung.

Djazuli, A. 2006. Kaidah-Kaidah Hukum. Kencana, Jakarta. H.L.A.Hart. 2011, Konsep hukum. Nusa Media, Bandung.

Ibrahim Gultom, 2010, Agama Malim di Tanah Batak, Bumi Aksara, Jakarta 
IGM Nurdjana, 2009 Hukum dan Aliran Kepercayaan Menyimpang di Indonesia, Pustaka Pelajar, Jogjakarta.

Iman Setiadi Arif, 2011. Dinamika Kepribadian: Gangguan dan Terapinya, PT Refika Aditama, Bandung

Iqbal, M. 2014. Fiqh Siyasah Kontekstual Doktrin Politik Islam. Prenada Media, Jakarta:

Ismail, M. Hilir. 2008. Kebangkitan Islam Dana Mbojo (Bima). Binasti. Bogor.

Jan Michiel Otto terjemahan Tristam Moeliono dalam Shidarta, 2006, Moralitas Profesi Hukum Suatu Tawaran Kerangka Berfikir,PT Revika Aditama, Bandung.

Maulana, Ali Muhammad, 1995 Islamologi, Darul Kutubil Islamiyah, Jakarta. Petir Abimanyu, 2014. Buku Pintar Aliran Kebatinan dan Ajarannya, Laksana, Jogjakarta.

Ridwan, HR,2003,Hukum Administrasi Negara, UII Pres, Yogyakarta. Philipus M. Hadjon,1998, Penataan Hukum Administrasi. Fakultas Hukum Unair, Surabaya.

Shidarta, 2006. Moralitas Profesi Hukum Suatu Tawaran Kerangka Berfikir. PT Revika Aditama, Bandung.

Sudikno Mertokusumo dalam H. Salim Hs, 2010, Perkembangan Teori Dalam Ilmu Hukum, PT Rajagrafindo Persada, Jakarta.

Suntana, Ija. 2010. Kapita Selekta Politik Islam. Pustaka Setia, Jakarta. 